\title{
Morphological aspects of atrioventricular valves in the ostrich (Struthio camelus)
}

\author{
Marcelo Abidu-Figueiredo ${ }^{{ }^{*}}$ \\ Clarice Machado dos Santos ${ }^{2}$ \\ Marco A. Pereira-Sampaio ${ }^{2}$ \\ Mauricio Alves Chagas ${ }^{2}$ \\ ${ }^{1}$ Federal Rural University of Rio de Janeiro \\ Br 465, Km 7, s/n, CEP 23851-970, Seropédica - RJ, Brazil \\ ${ }^{2}$ Fluminense Federal University, Niterói - RJ, Brazil \\ * Corresponding author \\ marceloabidu@gmail.com
}

Submetido em 21/04/2013

Aceito para publicação em 29/07/2013

\section{Resumo}

Aspectos morfológicos das valvas atrioventriculares no avestruz (Struthio camelus). A anatomia do coração do avestruz tem sido relatada, mas são escassas as informações sobre as características histológicas das valvas atrioventriculares. Corações de avestruzes jovens foram fixados em formol a 10\% por $24 \mathrm{~h}$ e dissecados para caracterização da anatomia macroscópica. Amostras das válvulas foram processadas e coradas com tricrômico de Mallory, tricrômico de Gomori e Picro-Sirius red, para posterior análise. A valva atrioventricular direita consiste em uma lâmina muscular com duas fixações. A válvula atrioventricular esquerda consiste em duas camadas de endocárdio com uma camada de tecido conjuntivo entre elas. A borda livre da válvula tricúspide sustenta um número variável de cordas tendíneas. Uma das cúspides se situa contra o septo, enquanto as outras duas cúspides na parede oposta. A valva aórtica, assim como a valva do tronco pulmonar, é formada por três valvulas. A valva atrioventricular direita apresentou-se apenas como uma lâmina muscular de miocárdio revestida por uma fina camada de tecido conjuntivo denso, com duas fixações. No tecido conjuntivo encontramos predominância de fibras colágenas do tipo I e, em menor quantidade, do tipo III, com uma presença discreta de fibras elásticas. Também foi comum a presença de fibras de Purkinje no subendocárdio valvular, sugerindo que elas participam diretamente na condução do estímulo nervoso para as fibras musculares no interior das válvulas. A valva atrioventricular esquerda consistiu em três válvulas, uma dorsal, uma esquerda e uma septal.

Palavras-chave: Anatomia; Avestruz; Histologia; Valva atrioventricular.

\section{Abstract}

Heart anatomy in the ostrich has been reported, but there are few information on the histological features of the atrioventricular valves. Hearts of young ostriches were fixed in 10\% formaldehyde for $24 \mathrm{~h}$ and dissected to characterize their macroscopic anatomy. Samples of valves were harvested and stained with Mallory's trichrome, Gomori's trichrome, and Picro-Sirius red, for later analysis. The right atrioventricular valve consists of a muscle flap with two fixations. The left atrioventricular valve consists of two layers of endocardium with a layer of 
connective tissue between them. The free border of the tricuspid valve supports a varying number of chordae tendineae. One of the cusps is attached to the septum, while the other two cusps are attached to the opposite wall. The aortic valve, as well as the pulmonary trunk valve, consists of three cusps. The right atrioventricular valve showed up only as a muscle flap of myocardium coated with a thin layer of dense connective tissue, with two fixations. In the connective tissue, we find a predominance of type I collagen fibers and a lesser amount of type III, with a small presence of elastic fibers. The presence of Purkinje fibers were also usual in the valvular subendocardium, suggesting that they directly participate in the transmission of nervous stimulation to the muscle fibers within the valves. The left atrioventricular valve consisted of 3 cusps, a dorsal, a left, and a right.

Key words: Anatomy; Atrioventricular valve; Histology; Ostrich

\section{Introduction}

Commercial breeding of ostriches has been carried out in Brazil. It is a recent trend and the Brazilian Institute of Environment and Renewable Natural Resources (IBAMA) included the ostrich in a list of domestic and commercial animal species by means of a law enacted in March 2002. The Black Neck ostrich (African Black ostrich) is the most common breed found on the Brazilian farms.

Although the first studies on the ostrich anatomy were carried out in the $19^{\text {th }}$ century (HUXLEY, 1867; MERREM, 1813), there is few specific data on ostrich morphology. Heart anatomy in the ostrich has been reported (BEZUIDENHOUT, 1984; 1999; FIGUEROA; HENRÍQUEZ-PINO, 2009; TADJALLI et al., 2009), but there are few reports on the histological features of the atrioventricular valves.

The ostrich heart is located within the pericardial sac in an oblique position, surrounded by the sternum and the first three rib pairs, providing the organ with protection. There is an important relation between the heart apex and the liver lobes (TADJALLI et al., 2009). The base of the heart is separated from the trachea and esophagus by the median portion of the clavicular sac, while the intrathoracic portion of the clavicular sac is located between the heart and sternum (BEZUIDENHOUT, 1999). Although the ostrich heart is quite different from the mammals' heart, mainly with regard to the anatomy of vessels and valves (BEZUIDENHOUT, 1999), there is no detailed report on the structure of atrioventricular valves in the ostrich.

This paper aims to provide a detailed morphological report on the atrioventricular valves in the ostrich.

\section{Materials and Methods}

We used 30 ostriches, from 1 to 15 days old, being 15 male and 15 female individuals. These specimens were donated by commercial breeders after natural death. The cardiac chambers were washed with saline and flushed with $10 \%$ buffered formalin. Then, the hearts were immersed in $10 \%$ buffered formalin for 2 weeks. The hearts were dissected by means of three different approaches: a transversal cut into the coronary sulcus was made in 10 hearts; a sagittal cut into the right ventricular wall was made in 10 hearts; and a sagittal cut into the left ventricular wall was made in the other 10 hearts. The macroscopic aspects of atrioventricular valves were recorded. A portion of each valve was taken out for microscopic analysis. The histological slides were prepared through the usual techniques and $5 \mu \mathrm{m}$ thick slices were stained with Gomori's trichrome and Mallory's trichrome, for general evaluation, and with Picro-Sirius red with polarized light microscopy, for evaluating the collagen fibers. The histological slides were examined using a microscope Olympus BX-51 and the images were recorded using a camera Sony DP-12.

\section{Results}

\section{Gross anatomy}

The right atrioventricular valve (RAV) consists of two laminae, a primary and a secondary, in all hearts. The RAV presents three attachments: central, septal, and dorsal. The central attachment holds both primary and secondary laminae on the ventricular wall. The primary lamina derives from the central attachment and reaches the heart apex, where it joins the trabeculae carneae. 
The secondary lamina also derives from the central attachment, but it joins the interventricular septum, close to the base of the heart (Figure 1A).

There is a small blind sac between the central attachment and the ventricular wall. There is no papillary muscle and chordae tendineae in the right ventricle and the free border of the RAV is sharp. The ventricular wall, distally to the central attachment, has a rough surface, while the interventricular wall, on the conus arteriosus, and the RAV has a smooth surface (Figure 1A).

The left atrioventricular valve (LAV) consists of three thin cusps with a double layer of endocardium. The right cusp is attached to the septal portion of the fibrous atrioventricular ostium. The two remaining cusps are attached to the ventricular portion of the fibrous atrioventricular ostium, one to the left side and the other to the dorsal face. The free border of all cusps supports several chordae tendineae, which are attached to the papillary muscles. There is a papillary muscle for each cusp, with a varying number of chordae tendineae (Figure 1B). The number of chordae tendineae from papillary muscles varied as listed in Table 1.

TABLE 1: Number of chordae tendineae from papillary muscles for each cusp of the left atrioventricular valve in the ostrich heart.

\begin{tabular}{cccc}
\hline $\begin{array}{c}\text { Number of chordae } \\
\text { tendineae from } \\
\text { papillary muscles }\end{array}$ & $\begin{array}{c}\text { Right } \\
\text { cusp }\end{array}$ & $\begin{array}{c}\text { Dorsal } \\
\text { cusp }\end{array}$ & $\begin{array}{c}\text { Left } \\
\text { cusp }\end{array}$ \\
\hline 2 & 8 & - & - \\
3 & 13 & 10 & - \\
4 & 9 & 11 & - \\
5 & - & 9 & - \\
6 & - & - & - \\
7 & - & - & 6 \\
8 & - & - & 7 \\
9 & - & - & 6 \\
10 & - & - & 5 \\
11 & - & - & 6 \\
\hline
\end{tabular}

FIGURE 1: Photomacrography of heart in the ostrich. A. Lateral view of the opened right ventricle, showing the primary and secondary laminae of the right atrioventricular valve. * Primary lamina, ** secondary lamina. B. Laterodorsal view of the opened left ventricle, showing the cusps of the left atrioventricular valve. $\mathrm{L}-$ left ventricular wall, $\mathrm{R}-$ right ventricular wall, $\mathrm{S}-$ ventricular septum, A - right cusp, B - left cusp, C - dorsal cusp.
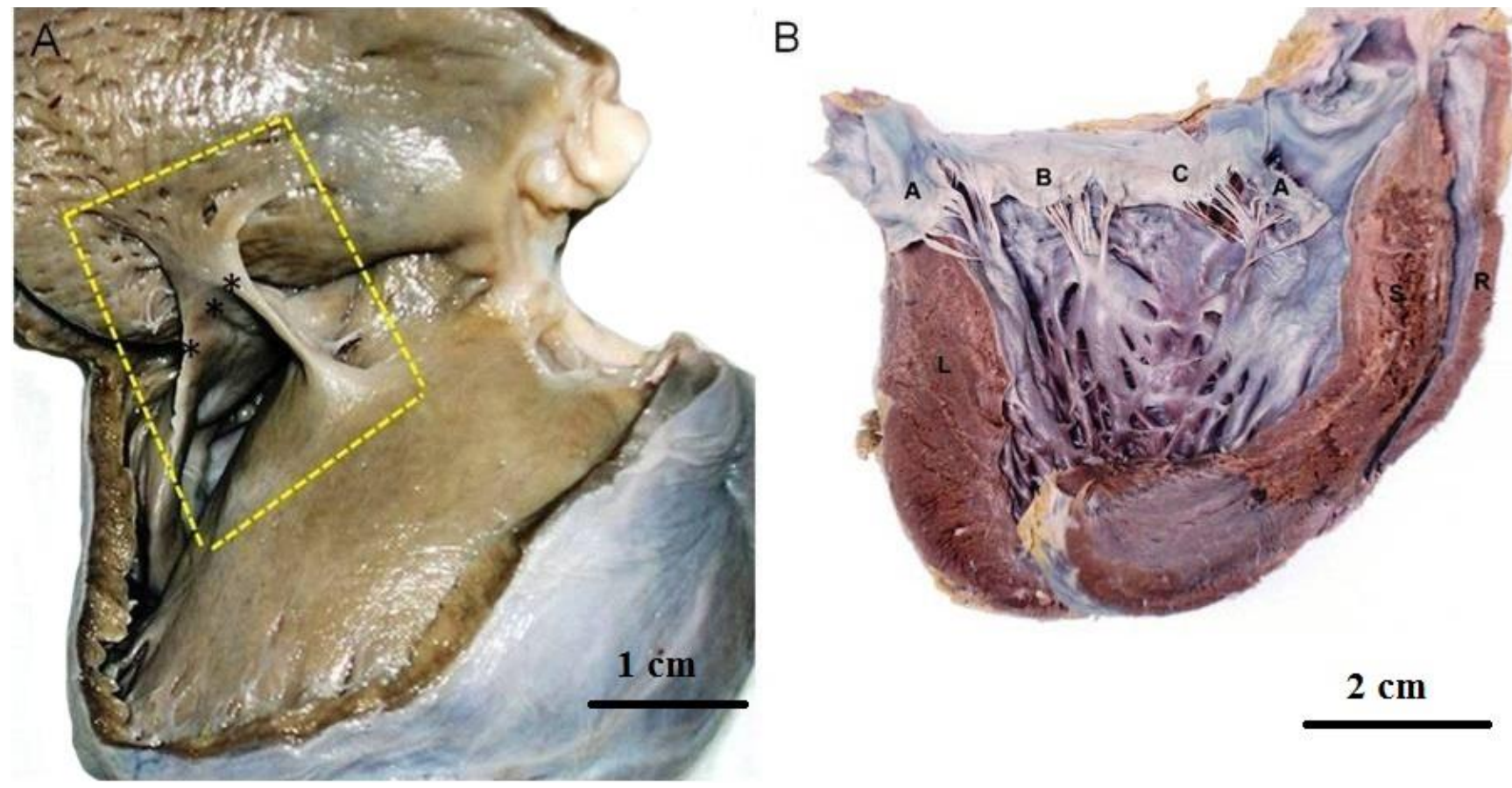


\section{Histology}

The RAV consists of a muscle layer covered by a thin layer of connective tissue and endothelium (Figure 2A). The muscle fibers are continuous with the myocardium from the septum and the ventricular wall. There are a small number of elastic fibers in the RAV and they are confined to subendothelial region. Purkinje fibers are found in a typical subendocardial course (Figure 2B).

The cusps of the LAV consist of a layer of connective tissue, with no muscle fibers covered by endocardium on both sides. The connective layer is made up by thick bundles of type I collagen fibers and thin bundles of type III collagen fibers (Figure 2C).

\section{Discussion}

Although the gross anatomy of atrioventricular valves in the ostrich has been studied (FIGUEROA; HENRÍQUEZ-PINO, 2009; TADJALLI et al., 2009), there is a lack of detailed information on their histological structure. Several authors (SCHWARZE; SCHRODER, 1970; NICKEL et al., 1977; GETTY, 1981) described the RAV in fowls as a muscle lamina without papillary muscles and chordae tendineae, and they reported the LAV with 3 cusps, 3 papillary muscles, and chordae tendineae in fowls.

In fowls, the internal surface of the ventricle contains the trabeculae carneae, but these muscles are more prominent in the left ventricle than in right ventricle (FIGUEROA; HENRÍQUEZ-PINO, 2009). In

FIGURE 2: Photomicrography of the right atrioventricular valve in the ostrich. A. Muscle fiber (MF) and the presence of Purkinje fibers (PF). Gomori's trichrome (40x). B. Endothelium made up of typical squamous cells (arrow) and subendothelial region (*). Purkinje fibers (PF) and muscle fiber (MF). Mallory's trichrome (40x). C. The connective layer is made up by thick bundles of type I collagen fibers (orange/red birefringence) and thin bundles of type III collagen fibers (green birefringence). Picro-Sirius red (40x).
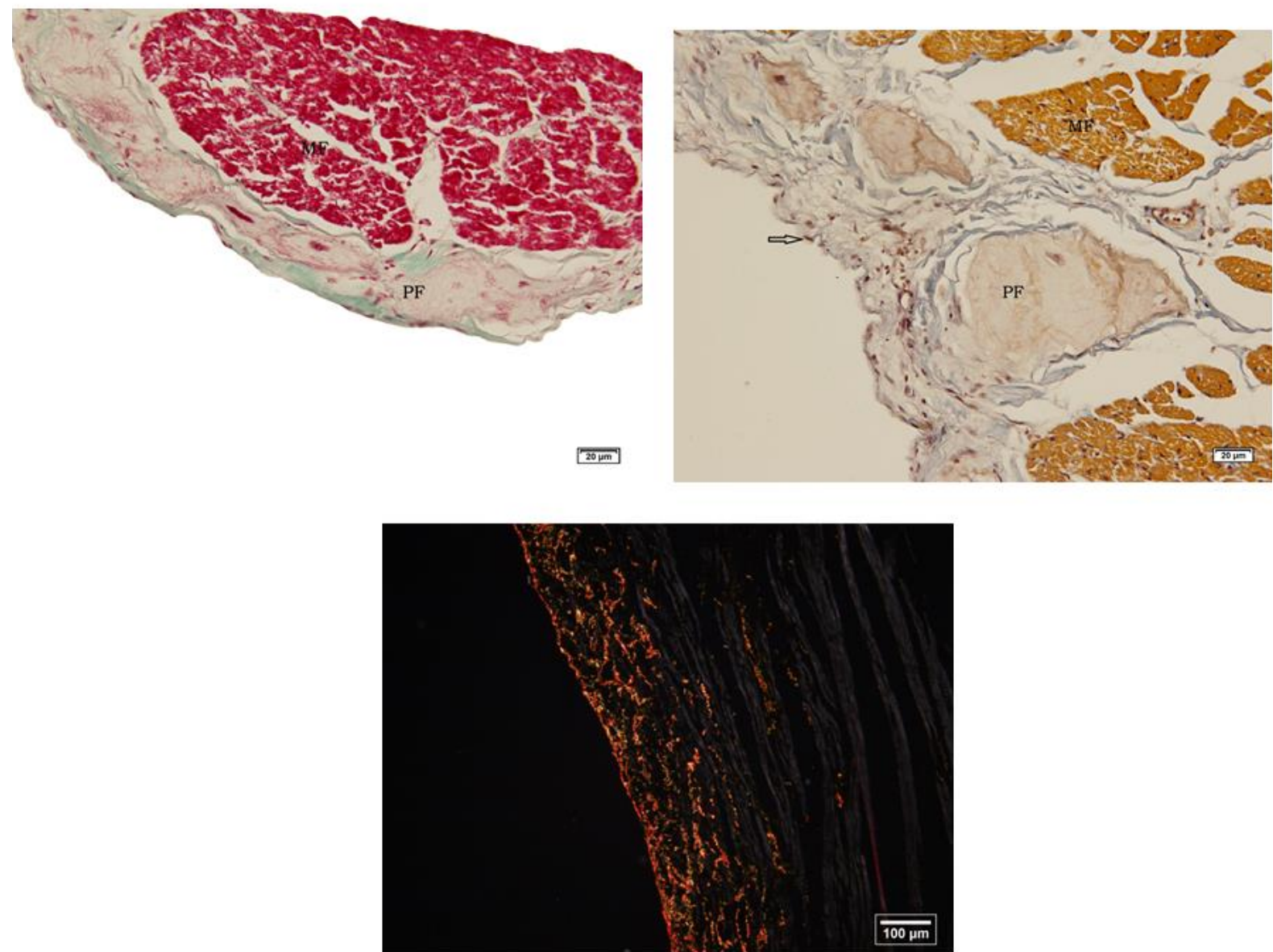
the ostrich, the trabeculae carneae are more prominent in the right ventricular wall than in the septum, and it has also been reported that the trabeculae carneae are found in a greater number at the ventricle apex (TADJALLI et al., 2009). We agree with these authors: the trabeculae carneae in the ostrich heart are more pronounced in the left ventricle than in the right ventricle. The lack of prominence of the trabeculae carneae on the septal surface in the right ventricle may help the RAV closure during the systolic phase, allowing the perfect overlap between the free border of the RAV and the septal surface.

The RAV in fowls consists of external laminae from the ventricular muscles and internal laminae from the atrial muscles (GETTY, 1981; BAUMEL et al., 1993). Bezuidenhout (1984) showed that the ventricular component of the RAV in ostrich consists of the cranial portion of the musculi longitudinalis ventriculi dextri and that the valve is located between the subsinuosal interventricular groove and the dorsal portion of the right ventricle. In fowls, the RAV is attached to the external wall of the right ventricle, to the ventricular dorsal face and to the septum (NICKEL et al., 1977; GETTY, 1981). In the ostrich, there are three attachments of the RAV, to the fibrous ring into the atrioventricular orifice, to the septum by a short left septal attachment, and to the parietal wall by a thick muscle stalk (TADJALLI et al., 2009). Figueroa and Henríquez-Pino (2009) described a dorsal and a ventral attachment of the RAV in the ostrich, but they only found the third attachment to the lateral wall in 1 out of the 50 animals under study. Bezuidenhout (1999) also described only two attachments of the RAV in the ostrich. The RAV in the animals analyzed in this study was attached in three points, dorsally to the fibrous ring of the atrioventricular orifice, ventrally to the septum, and close to the middle of the valve free border to the external wall, by a muscle stalk. The space between the external surface of the RAV and the external wall of the ventricle forms a fornix, which communicates with the conus arteriosus. This fornix was previously described in fowls by means of a term in French, "culde-sac" (GETTY, 1981).

The LAV in fowls consists of three cusps: left, dorsal, and right (HODGES, 1974; GETTY, 1981;
NICKEL et al., 1977). In ostriches, there are also three cusps: left, dorsal, and right (BEZUIDENHOUT, 1999). We found three cusps in the LAV of the ostrich heart, left, dorsal, and right. The right cusp is the largest and it is attached to the interventricular septum. Each cusp of the LAV receives chordae tendineae from two papillary muscles, as previously found in fowls (GETTY, 1981) and in ostriches (TADJALLI et al., 2009). There are three papillary muscles in the left ventricle, ventral, dorsal and septal. This finding corroborates that reported by Figueroa and Henríquez-Pino (2009), who also observed three papillary muscles in the ostrich heart, but they named these muscles anterior, posterior, and septal. As the heart is in an oblique position, we think that "dorsal" and "ventral" seem to constitute more adequate terms than "anterior" and "posterior", due the location of valves.

The cusps of the LAV consist of a double layer of endocardium and an intermediate fibrous tissue. It has been shown, using Picro-sirius red staining and circularly polarized light microscope, that the fibrous tissue is made up by thick bundles of type I collagen fibers and thin bundles of type III collagen fibers.

In both valves, the Purkinje fibers are subendocardial (GETTY, 1981; BAUMEL et al., 1993; FIGUEROA; HENRÍQUEZ-PINO, 2009). The atrioventricular bundle divides into the interventricular septum in right and left crura, sending subendocardial branches (GETTY, 1981; BAUMEL et al., 1993). The right crus of the atrioventricular bundle sends a branch to the RAV in the septal attachment (GETTY, 1981). Figueroa and Henríquez-Pino (2009) described two branches for RAV, one in the dorsal and the other in the ventral attachment.

The presence Purkinje fibers in the RAV suggests a similar mechanism previously described in fowls (DAVIES, 1930; LU et al., 1993), where the Purkinje fibers of the RAV stimulate the RAV muscle fibers before the ventricular myocardium, actively closing the right atrioventricular orifice. During the systole, the increased intraventricular pressure passively completes the closure. This mechanism is different from the left atrioventricular valve, where the closure of the left atrioventricular orifice is solely passive. 
By way of conclusion, our findings suggest that the heart valve apparatus in the ostrich is very similar to that found in other bird species, despite the extreme differences in heart size and heart rate.

\section{Acknowledgment}

The authors thank to FAPERJ and CNPq, for financial support.

\section{References}

BAUMEL, J. J.; KING, A. S; BREAZILE, J. E.; EVANS, H. E.; VANDEN BERGE, J. C. Handbook of Avian Anatomy: Nomina Anatomica Avium. 2. ed. Cambridge: Nuttall Ornithological Club, 1993. $721 \mathrm{p}$.

BEZUIDENHOUT, A. J. The coronary circulation of the heart of the ostrich (Struthio camelus). Journal of Anatomy, London, v. 138, n. 3, p. 385-397, 1984.

BEZUIDENHOUT, A. J. The ostrich: biology, production and health. Oxon: CAB International, 1999. 347 p.

DAVIES, F. The conducting system of the bird's heart. Journal of Anatomy, London, v. 64, n. 2, p. 129-144, 1930.
FIGUEROA, M.; HENRÍQUEZ-PINO, J. Papillary muscles in the heart of the ostrich (Struthio camelus). International Journal of Morphology, Temuco, v. 27, n. 2, p. 435-440, 2009.

GETTY, R. Anatomia dos animais domésticos. Rio de Janeiro: Interamericana, 1981. $1134 \mathrm{p}$.

HODGES, R. D. Histology of the fowl. London: Academic Press, 1974. $648 \mathrm{p}$

HUXLEY, T. H. On the classification of birds; and on the taxonomic value of the modifications of certain cranial bones observable in that class. Proceedings of the Zoological Society of London, London v. 3, n. 4, p. 415-472, 1867.

LU, Y.; JAMES, T. N.; BOOTSMA, M.; TERASAKI, F. Histological organization of the right and left atrioventricular valves of the chicken heart and their relationship to the atrioventricular purkinje ring and the middle bundle branch. Anatomical Record, Philadelphia, v. 235, n. 1, p. 74-86, 1993.

MERREM, B. Tentamen systematis naturalis avium. Königlich Preussichen Akademie der Wissenschaft, Berlin, v. 13, n. 7, p. 237-259, 1813.

NICKEL, R.; SCHUMMER, A.; SEIFERLE, E. Anatomy of the domestic birds. Berlin: Verlag Paul Parey, 1977. 202 p.

SCHWARZE, E.; SCHRODER, L. Compêndio de anatomia veterinária. Vol. 5. Zaragoza: Acríbia, 1970. 212 p.

TADJALLI, M.; GHAZI, S. R.; PARTO, P. Gross Anatomy of the heart in ostrich (Struthio camelus). Iranian Journal of Veterinary Research, Shiraz, v. 10, n. 1, p. 21-27, 2009. 